\title{
A Critical Role of Lateral Hypothalamus in Context-Induced Relapse to Alcohol Seeking after Punishment-Imposed Abstinence
}

\author{
Nathan J. Marchant, ${ }^{1,3}$ Rana Rabei, ${ }^{1}$ Konstantin Kaganovsky, ${ }^{1}$ Daniele Caprioli, ${ }^{1}$ Jennifer M. Bossert, ${ }^{1}$ \\ Antonello Bonci, ${ }^{2,4,5}$ and Yavin Shaham ${ }^{1}$ \\ ${ }^{1}$ Behavioral Neuroscience Research Branch and ${ }^{2}$ Cellular Neurobiology Research Branch, Intramural Research Program, National Institute on Drug Abuse, \\ National Institutes of Health, Department of Health and Human Services, Baltimore, Maryland 21224, ${ }^{3}$ Florey Institute of Neuroscience and Mental Health, \\ University of Melbourne, Parkville, Victoria 3052, Australia, ${ }^{4}$ Solomon H. Snyder Department of Neuroscience and ${ }^{5}$ Department of Psychiatry, Johns \\ Hopkins University, Baltimore, Maryland 21287
}

In human alcoholics, abstinence is often self-imposed, despite alcohol availability, because of the negative consequences of excessive use. During abstinence, relapse is often triggered by exposure to contexts associated with alcohol use. We recently developed a rat model that captures some features of this human condition: exposure to the alcohol self-administration environment (context A), after punishmentimposed suppression of alcohol self-administration in a different environment (context B), provoked renewal of alcohol seeking in alcohol-preferring $P$ rats. The mechanisms underlying context-induced renewal of alcohol seeking after punishment-imposed abstinence are unknown. Here, we studied the role of the lateral hypothalamus (LH) and its forebrain projections in this effect. We first determined the effect of context-induced renewal of alcohol seeking on Fos (a neuronal activity marker) expression in LH. We next determined the effect of $\mathrm{LH}$ reversible inactivation by $\mathrm{GABA}_{\mathrm{A}}+\mathrm{GABA}_{\mathrm{B}}$ receptor agonists (muscimol + baclofen) on this effect. Finally, we determined neuronal activation in brain areas projecting to $\mathrm{LH}$ during context-induced renewal tests by measuring double labeling of the retrograde tracer cholera toxin subunit B (CTb; injected in $\mathrm{LH}$ ) with Fos. Context-induced renewal of alcohol seeking after punishment-imposed abstinence was associated with increased Fos expression in LH. Additionally, renewal was blocked by muscimol + baclofen injections into LH. Finally, double-labeling analysis of CTb + Fos showed that context-induced renewal of alcohol seeking after punishment-imposed abstinence was associated with selective activation of accumbens shell neurons projecting to LH. The results demonstrate an important role of LH in renewal of alcohol seeking after punishment-imposed abstinence and suggest a role of accumbens shell projections to $\mathrm{LH}$ in this form of relapse.

Key words: alcohol; context; lateral hypothalamus; nucleus accumbens; punishment; relapse

\section{Introduction}

In humans, exposure to environmental contexts associated previously with drug and alcohol use can provoke relapse during abstinence (Wikler, 1973; McCusker and Brown, 1990; O’Brien et al., 1992; Collins and Brandon, 2002). To model this human condition, we and others used an ABA renewal procedure (Bouton and Bolles, 1979; Bouton, 1993) in which rats are first trained to self-administer drug in one context (A) and subsequently given operant extinction training in a different context (B). Re-

\footnotetext{
Received Jan. 16, 2014; revised March 7, 2014; accepted April 16, 2014.

Author contributions: N.J.M. and Y.S. designed research; N.J.M., R.R., K.K., D.C., and J.M.B. performed research; N.J.M. and Y.S. analyzed data; N.J.M., A.B., and Y.S. wrote the paper.

This work was supported by the National Institute on Drug Abuse, Intramural Research Program. N.J.M. received support from Early Career Fellowship 1053308 by the National Health and Medical Research Council.

The authors declare no competing financial interests.

Correspondence should be addressed to either Nathan Marchant or Yavin Shaham, Biomedical Research Center, Room 08A721, 251 Bayview Boulevard, Baltimore, MD 21224. E-mail: nathan.marchant@nih.gov, yavin.shaham@nih.gov.

DOI:10.1523/JNEUROSCI.0256-14.2014

Copyright $\odot 2014$ the authors $\quad 0270-6474 / 14 / 347447-11 \$ 15.00 / 0$
}

newal (also termed context-induced reinstatement) of alcohol seeking is observed when rats are tested in context A under extinction conditions (Crombag et al., 2008; Fuchs et al., 2008b; Janak and Chaudhri, 2010). However, from a human relapse perspective, a limitation of this procedure, and the extinction-reinstatement model in general, is the use of operant extinction to achieve abstinence (Epstein and Preston, 2003; Katz and Higgins, 2003). In contrast, in humans, abstinence is often self-imposed despite drug availability, because the rewarding effects of the drug are outweighed by aversive consequences of drug use (Klingemann, 1991; Burman, 1997; Blume et al., 2006).

Based on these considerations, we recently developed a modified $A B A$ renewal procedure in which abstinence is achieved in context B, despite alcohol availability, by response-contingent footshock (punishment manipulation). During testing, alcohol seeking is assessed under extinction conditions without shock in contexts A and B (Marchant et al., 2013b). We found that renewal of alcohol seeking is provoked by exposing rats to context $A$ after punishment-imposed suppression of alcohol taking in context B. This effect was as reliable as context-induced renewal of alcohol 
seeking after extinction and was critically dependent on the contingency between shock and alcohol-reinforced lever pressing in context B. We found no difference in either alcohol selfadministration in context $\mathrm{B}$, or alcohol-seeking on test in contexts $\mathrm{A}$ and $\mathrm{B}$, between rats that received noncontingent (random) shock in context B and rats that were not punished (Marchant et al., 2013b).

The brain mechanisms of context-induced renewal of alcohol seeking after punishment-imposed abstinence are unknown. Here, we studied the role of the lateral hypothalamus (LH) in this form of relapse. The LH was traditionally associated with feeding and motivated behavior in general (Hoebel and Teitelbaum, 1962; Margules and Olds, 1962; Kelley and Berridge, 2002). More recently, the LH was implicated in reinstatement of morphine conditioned place preference (Harris et al., 2005; Harris and Aston-Jones, 2006) and context-induced reinstatement of alcoholic beer seeking after extinction (Marchant et al., 2009, 2012).

We first determined whether context-induced renewal of alcohol seeking after punishment-imposed abstinence is associated with induction of the neuronal activity marker Fos in LH and in LH hypocretin neurons (de Lecea et al., 1998), which were implicated in drug reward and reinstatement after extinction (AstonJones et al., 2010; Marchant et al., 2012). We then determined the effect of reversible inactivation of $\mathrm{LH}$ by $\mathrm{GABA}_{\mathrm{A}}+\mathrm{GABA}_{\mathrm{B}}$ receptor agonists (muscimol + baclofen; McFarland and Kalivas, 2001) on context-induced renewal of alcohol seeking. Finally, we determined neuronal activation in forebrain projections to $\mathrm{LH}$ during the renewal tests by measuring double labeling of the retrograde tracer cholera toxin subunit $\mathrm{B}$ (CTb; injected into $\mathrm{LH}$ ) with Fos. We focused on nucleus accumbens (NAc) shell, ventral (vmPFC) and dorsal (dmPFC) medial prefrontal cortex, lateral septum (LS), and ventral (vBNST) and dorsal (dBNST) bed nucleus of the stria terminalis, which all have dense projections to LH (Heimer et al., 1991; Zahm and Heimer, 1993). We also measured Fos expression in NAc core, dorsal striatum, and paraventricular thalamus (PVT) because of their role in context-induced reinstatement of alcohol and cocaine seeking (Bossert et al., 2013; McNally, 2014), as well as medial (MHb) and lateral (LHb) habenula, recently implicated in inhibition of reward seeking and aversive conditioning (Friedman et al., 2011; Jhou et al., 2013).

\section{Materials and Methods}

\section{Subjects and apparatus}

We received male alcohol-preferring $\mathrm{P}$ rats $(\sim 30 \mathrm{~d}$ old, $n=69)$ from Indiana University and housed them singly under a reversed $12 \mathrm{~h}$ light/ dark cycle (8:00 AM lights off) with access to food and water ad libitum. We performed the experiments in accordance with the National Institutes of Health Guide for the Care and Use of Laboratory Animals (eighth edition); protocols were approved by the Animal Care and Use Committee. For home-cage drinking, we made alcohol solutions [prepared in tap water from $100 \%(\mathrm{v} / \mathrm{v})$ ethanol] in standard water bottles. For alcohol self-administration, we used standard operant chambers (Med Associates), each enclosed in a ventilated sound-attenuating cubicle and illuminated by a house light. The chambers were equipped with one retractable lever (designated as "active") and one nonretractable lever (designated as "inactive"); the grid floors were connected to shockers. We delivered alcohol $(0.1 \mathrm{ml} /$ delivery $)$ into receptacles via 12 -gauge blunt needles connected to $60 \mathrm{ml}$ syringes controlled by a Razel pump. We manipulated and counterbalanced contexts A and B as described by Marchant et al. (2013b): (1) grid width (narrow/wide); (2) illumination level (white/red house light); (3) background noise (fan on/off); and (4) background cues (feeder present/absent, cabinet doors close/open).

\section{Behavioral procedure (four phases)}

Phase 1: home-cage alcohol intake. We used an intermittent-access (three to four times per week) alcohol procedure (Wise, 1973; Simms et al.,
2008) in which rats received 12 24-h sessions of access to one bottle of $20 \%$ ethanol and one water bottle (Marchant et al., 2013b).

Phase 2: operant self-administration, context A. We gave rats two 2-h "magazine training" sessions in which $0.1 \mathrm{ml}$ of alcohol and $2 \mathrm{~s}$ tone-light cue were delivered noncontingently every $5 \mathrm{~min}$. Subsequently, we trained rats for six $2 \mathrm{~h}$ sessions to self-administer $0.1 \mathrm{ml}$ deliveries of alcohol on a fixed ratio 1 (FR-1) $20 \mathrm{~s}$ timeout reinforcement schedule. Lever presses on the active lever resulted in presentation of the $2 \mathrm{~s}$ tone-light cue and activation of the infusion pump. Lever presses on the inactive lever had no consequences. Next, we trained rats on a variable-interval $30 \mathrm{~s}$ (VI-30) reinforcement schedule for six sessions. During these sessions, alcohol delivery was available after an active lever press at random intervals (1-59 s) after the preceding alcohol delivery.

Phase 3: punishment, context $B$. We trained the rats to self-administer alcohol in context B ( $2 \mathrm{~h}$ sessions) under the VI-30 reinforcement schedule. Lever presses on the active retractable lever resulted in presentation of the $2 \mathrm{~s}$ tone-light cue and activation of the infusion pump, with $50 \%$ of the reinforced lever presses leading to $0.5 \mathrm{~s}$ footshock $(0.3-0.75 \mathrm{~mA})$. Punished lever presses resulted in $0.5 \mathrm{~s}$ shock at the same time as the $2 \mathrm{~s}$ tone-light cue and alcohol delivery. The shock intensity was $0.3 \mathrm{~mA}$ for the first three sessions. We set our "suppression threshold" at 15 active lever presses per session. If rats were above this threshold, we increased shock intensity by $0.15 \mathrm{~mA}$ increments in the subsequent session. Once rats were below this threshold for $\geq 2 \mathrm{~d}$, we tested them for contextinduced renewal of alcohol seeking.

Phase 4: relapse tests. We tested rats for alcohol seeking (active lever presses under extinction conditions) without punishment or alcohol in contexts A and/or B. During testing, the $2 \mathrm{~s}$ tone-light cue was presented after active lever presses under the VI-30 reinforcement schedule.

\section{Surgery}

We performed all surgeries after the home-cage drinking phase. We anesthetized rats with either $100 \mathrm{mg} / \mathrm{kg}$ ketamine $+10 \mathrm{mg} / \mathrm{kg}$ xylazine (intraperitoneally) or sodium pentobarbital $(70 \mathrm{mg} / \mathrm{kg}$, i.p. $)+$ atropine sulfate $(0.05 \mathrm{mg} / \mathrm{kg}$, s.c. $)$; we gave the rats the analgesic buprenorphine $(0.1 \mathrm{mg} / \mathrm{ml} ; 0.1 \mathrm{ml} / \mathrm{rat}$, s.c. $)$ after surgery and allowed them to recover for $3-5 \mathrm{~d}$.

Intracranial surgery. We implanted guide cannulas (23 gauge; Plastics One) $1 \mathrm{~mm}$ above the target site (LH or dorsal to $\mathrm{LH}$ ). The coordinates for $\mathrm{LH}$ were as follows (nose bar set at $-3.3 \mathrm{~mm}$ ): anteroposterior (AP), -2.4 ; mediolateral (ML), \pm 3.5 ( $10^{\circ}$ angle); and dorsoventral (DV), -8.0 $\mathrm{mm}$ from bregma. The coordinates for dorsal to $\mathrm{LH}$ were the same except that DV was $-6.0 \mathrm{~mm}$. We anchored the cannulas to the skull with jeweler's screws and dental cement.

$\mathrm{CTb}$ surgery. We removed the bone above $\mathrm{LH}$ with a drill and injected $40 \mathrm{nl}$ of $1 \% \mathrm{CTb}$ (List Biological Laboratories) unilaterally into LH (AP, $-2.4 ; \mathrm{ML},+1.9 ; \mathrm{DV},-8.9 \mathrm{~mm}$ from bregma). We used a stereotaxically positioned $1.0 \mu \mathrm{l} 32$ gauge "Neuros" syringe (Hamilton) attached to a UMP4 injector (World Precision Instruments). We injected CTb into either the left or right hemisphere over $2 \mathrm{~min}$ and left the needle in place for 2 min after injections; next, we filled the skull hole with bone wax and sutured the skin.

\section{Intracranial injections}

We dissolved muscimol and baclofen (Tocris) in sterile saline and injected the mixture 5-10 min before testing. For the relapse tests, we used a dose of muscimol + baclofen (concentration, $0.06+0.6 \mathrm{~mm}$ or $3.6+64.1 \mathrm{ng}$ in $0.5 \mu \mathrm{l} / \mathrm{side}$ ) based on previous studies (McFarland and Kalivas, 2001; Bossert et al., 2012) and a preliminary experiment described below (see Specific experiments). The injectors extended $1 \mathrm{~mm}$ below the tips of the guide cannula. We injected vehicle or muscimol + baclofen over $1 \mathrm{~min}$ and left injectors in place for $1 \mathrm{~min}$. We used a syringe pump (Harvard Apparatus) connected to $10 \mu$ l Hamilton syringes attached via polyethylene-50 tubing to 30 gauge injectors. After the final test, we anesthetized the rats, removed their brains, and stored the brains in $10 \%$ Formalin. We verified cannula placements under a light microscope after brain sectioning $(40 \mu \mathrm{m})$, using a Leica cryostat and staining sections with cresyl violet. 


\section{Immunohistochemistry}

Immediately after the 90 min test (context A or B) or straight from the home cage for the no-test group, we anesthetized the rats with isoflurane and perfused them transcardially with $\sim 100 \mathrm{ml}$ of $0.1 \mathrm{M}$ PBS, followed by $\sim 400 \mathrm{ml}$ of $4 \%$ paraformaldehyde in $0.1 \mathrm{~m}$ sodium phosphate, $\mathrm{pH} 7.4$. We removed the brains and postfixed them in $4 \%$ paraformaldehyde for $2 \mathrm{~h}$ before transferring them to $30 \%$ sucrose in $0.1 \mathrm{~m}$ sodium phosphate, $\mathrm{pH} 7.4$, for $48 \mathrm{~h}$ at $4^{\circ} \mathrm{C}$. We froze the brains in dry ice and stored them at $-80^{\circ} \mathrm{C}$. We cut coronal sections $(40 \mu \mathrm{m})$ of the different brain areas using a cryostat. We divided the sections into four series (160 $\mu \mathrm{m}$ apart), collected them in $0.1 \mathrm{M}$ sodium phosphate, $\mathrm{pH} 7.4$, containing $1 \%$ sodium azide, and stored them at $4^{\circ} \mathrm{C}$.

Hypocretin + Fos double labeling. We washed free-floating sections for 30 min in PBS, then 50\% ethanol, then 50\% ethanol containing 3\% hydrogen peroxide, and then PBS containing 5\% normal horse serum (NHS). Next, we incubated the sections for at least $48 \mathrm{~h}$ at $4^{\circ} \mathrm{C}$ in PBS containing 0.5\% Triton X-100 (PBS-Tx) with 2\% NHS (H1138; Sigma) and rabbit anti-c-Fos primary antibody (c-Fos sc-52; Santa Cruz Biotechnology) diluted to 1:2000. We rinsed the sections in PBS and incubated them for $2 \mathrm{~h}$ in PBS-Tx containing 2\% NHS and biotinylated donkey anti-rabbit secondary antibody (711-065-152; Jackson ImmunoResearch), diluted to 1:2000. We rinsed the sections and incubated them for $1 \mathrm{~h}$ in PBS-Tx containing 2\% NHS and avidin-biotin-peroxidase complex (Vector Elite kit, PK-6100: $6 \mu \mathrm{l} / \mathrm{ml}$ avidin and $6 \mu \mathrm{l} / \mathrm{ml}$ biotin; Vector Laboratories). We then rinsed twice in PBS, followed by one rinse in $0.1 \mathrm{M}$ acetate buffer, $\mathrm{pH}$ 6.0. A black reaction product was generated by adding nickel sulfate hexahydrate to the DAB reaction solution. We gave the sections a $10 \mathrm{~min}$ rinse in $0.1 \mathrm{M}$ acetate buffer, $\mathrm{pH} 6.0$, containing $2 \%$ nickel sulfate, $0.025 \%$ 3,3-diaminobenzidine, $0.004 \%$ ammonium chloride, and $0.02 \%$ D-glucose. The peroxidase reaction was started by adding $0.2 \mu \mathrm{l} / \mathrm{ml}$ glucose oxidase and stopped after $8 \mathrm{~min}$ using quick successive washes in acetate buffer. We rinsed the sections in PBS and incubated them for $30 \mathrm{~min}$ in PBS containing $0.3 \% \mathrm{H}_{2} \mathrm{O}_{2}$ and rinsed them in PBS before $1 \mathrm{~h}$ incubation in PBS-Tx containing $4 \mathrm{drops} / \mathrm{ml}$ Avidin D from the avidin-biotin blocking kit (SP-2001; Vector Laboratories). We transferred the sections to the hypocretin primary antibody (H-003-30, lot \#01169-5; Phoenix Pharmaceuticals) diluted to 1:10,000 in PBS-Tx containing 2\% NHS and 4 drops/ml biotin from the avidinbiotin blocking kit and incubated them for $48 \mathrm{~h}$ at $4^{\circ} \mathrm{C}$. We rinsed the sections in PBS and treated exactly the same as the previous reaction but without nickel intensification to localize hypocretin-immunoreactive (IR) neurons, revealed as a brown reaction product. The reaction time was 6:30 min. We stored the sections in PBS at $4^{\circ} \mathrm{C}$ until they were mounted on gelatin-treated slides, dehydrated, cleared with Citrasolv (Thermo Fisher Scientific), and coverslipped with Permount (Thermo Fisher Scientific).

$\mathrm{CTb}+$ Fos double labeling. We rinsed free-floating sections (three times, 10 min each) and then incubated them in 10\% NHS with PBS-Tx for $2 \mathrm{~h}$. We then incubated the sections for at least $48 \mathrm{~h}$ at $4^{\circ} \mathrm{C}$ in PBS-Tx containing 2\% NHS and rabbit anti-c-Fos primary antibody (c-Fos sc52, lot E0212; Santa Cruz Biotechnology) diluted to 1:2000 and goat anti-CTb primary antibody (CTb 703; List Biological Laboratories) diluted to 1:5000. We rinsed the sections in PBS and incubated them for $3 \mathrm{~h}$ in PBS-Tx containing 2\% NHS and donkey anti-goat Alexa Fluor 488 (711-545-152; Jackson ImmunoResearch) and donkey anti-goat Alexa Fluor 594 (705-585-147; Jackson ImmunoResearch) diluted to 1:2000. We washed the sections three times in PBS (10 min washes) and mounted them onto gelatin-coated slides, partially dried, and coverslipped with Vectashield HardSet Mounting Medium (H-1400; Vector Laboratories).

\section{Neuronal counting}

For $\mathrm{CTb}+$ Fos, we digitally captured dark-field images of IR cells in the different brain areas using an EXi Aqua camera (QImaging) attached to a Zeiss Axio Scope 2, Axio Imager M2. We captured and analyzed the images using iVision (Biovision). Each image analyzed comprised five images through the $z$ plane that was digitally collapsed using iVision giving a single-plane view of in-focus cells. We identified CTb-IR neurons with fluorescent cytoplasm using the YFP filter and Fos-IR neurons with fluorescent nuclei using the RFP filter. For each rat, we quantified cells in both hemispheres. We analyzed two sections/brain areas in the following bregma coordinates: $\mathrm{mPFC},+3.3$ and $+2.8 \mathrm{~mm}$; NAc shell and core, +1.8 and $+1.5 \mathrm{~mm}$; dorsolateral (DLS) and dorsomedial (DMS) striatum, +1.5 and $+1.2 \mathrm{~mm}$; LS, +3.3 and $+2.8 \mathrm{~mm}$; BNST, +0.1 and $-0.3 \mathrm{~mm}$; and four sections per rat for PVT, LHb, and MHb $(-2.7,-3.1,-3.4$, and $-3.8 \mathrm{~mm})$. For NAc shell, we analyzed the dorsal and ventral subregions separately but combined the results because there were no differences in either Fos or CTb + Fos counts between the two subregions. For hypocretin + Fos, we digitally captured bright-field images over three sections per rat in $\mathrm{LH}(-2.7,-3.1$, and $-3.4 \mathrm{~mm})$. We performed the image-based quantification in a blind manner.

\section{Specific experiments}

Experiment 1: effect of context-induced renewal of alcohol seeking after punishment-imposed abstinence on Fos expression in LH hypocretin neurons. The rats $(n=21)$ underwent surgery (CTb injection) after the home-cage intake phase, but we did not perform CTb analysis in these rats. We then trained them to self-administer alcohol in context A and subsequently punished the alcohol-reinforced responding in context B. We tested rats under extinction condition in either context A or B once they were below the suppression threshold for two consecutive sessions. For rats that were above the threshold, we tested them after additional sessions at higher intensities $(+0.15 \mathrm{~mA}$ increments) until they were below the suppression threshold for two consecutive sessions. Thus, we gave rats between 3 and 7 context $\mathrm{B}$ punishment sessions before the renewal (context-induced reinstatement) test. After punishmentimposed suppression of alcohol taking, we either tested the rats in context A (renewal group; $n=8$ ) or context $\mathrm{B}$ ( punishment group; $n=8$ ) or did not test them (no-test group; $n=5$ ). Immediately after the $90 \mathrm{~min}$ test, we perfused the tested rats; we also perfused the no-test rats at the same time. Subsequently, we performed immunohistochemistry for hypocretin + Fos double labeling.

Experiment 2: effect of LH inactivation on context-induced renewal of alcohol seeking after punishment-imposed abstinence. In a preliminary experiment, we trained a group of rats under the four experimental phases described above and tested them for context-induced relapse after injections of a muscimol + baclofen dose $(0.1+1.0 \mathrm{~mm})$ that was higher than the dose used in Experiment $2(0.06+0.6 \mathrm{~mm})$. The $0.1+1.0 \mathrm{~mm}$ dose completely blocked context-induced renewal of alcohol seeking, but visual inspection of the rats suggested a potential sedative effect. Therefore, we retrained six rats to self-administer alcohol in context A under the VI-30 schedule and tested the effect of the lower dose used in Experiment 2 and half of this dose on ongoing alcohol intake. We found that neither dose significantly decreased alcohol intake: mean \pm SEM alcohol deliveries $/ 2 \mathrm{~h}$ were $30 \pm 5.6,32.8 \pm 4.9,25.7 \pm 3.3$ for the vehicle, $0.03+0.3$ $\mathrm{mm}$, and $0.06+0.6 \mathrm{~mm}$, respectively $(p>0.1)$. Therefore, we used the $0.06+0.6 \mathrm{~mm}$ muscimol + baclofen dose in Experiment 2 described below.

After the home-cage intake phase, we implanted the rats $(n=26)$ with guide cannulas above the $\mathrm{LH}$ or dorsal to $\mathrm{LH}(2 \mathrm{~mm})$. We then trained them to self-administer alcohol in context A and subsequently punished the alcohol-reinforced responding in context $\mathrm{B}$. We gave the rats that responded below the suppression threshold additional context B punishment sessions at the same shock intensity as the previous session. For rats that were above the threshold, we gave them additional sessions at higher intensity ( $+0.15 \mathrm{~mA}$ increments) until they were below the suppression threshold for two consecutive sessions, after which all rats were tested in the following sessions. We tested all rats in both contexts under extinction conditions over consecutive days (counterbalanced order). The groups were LH muscimol + baclofen $(n=10)$, LH vehicle $(n=9)$, and dorsal to LH muscimol + baclofen $(n=7)$.

Experiment 3: effect of context-induced renewal of alcohol seeking after punishment-imposed abstinence on Fos expression in brain areas projecting to $\mathrm{LH}$. After the home-cage intake phase, we gave the rats $(n=22) \mathrm{CTb}$ injections into LH. We then trained them to self-administer alcohol in context A and subsequently punished the alcohol-reinforced responding in context B. After punishment-induced suppression of alcohol seeking, we tested the rats either in context $\mathrm{A}$ (renewal group; $n=8$ ) or context $\mathrm{B}$ (punishment group; $n=8$ ) or did not test them (no-test group; $n=6$ ). 


\section{A}

\section{Behavioral procedure}

\begin{tabular}{|c|c|cc|} 
Phase 1: Home-cage & Phase 2: Context A & Phase 3: Context B & Renewal \\
test
\end{tabular}

B Home-cage
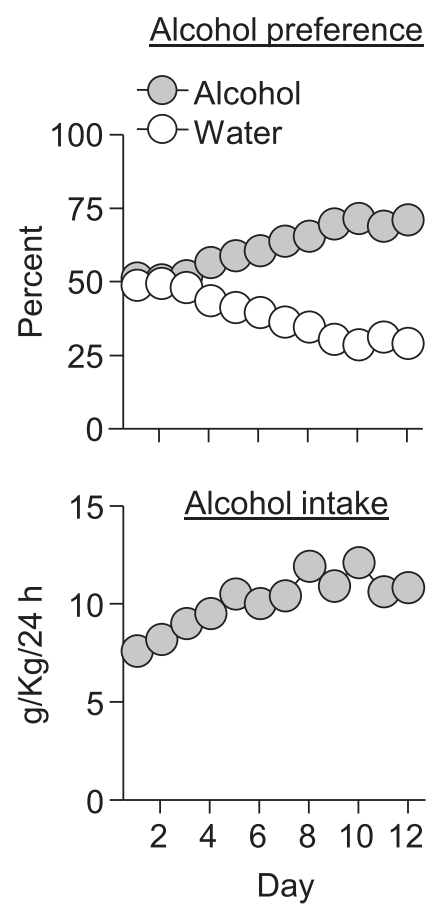

C Context A self-administration
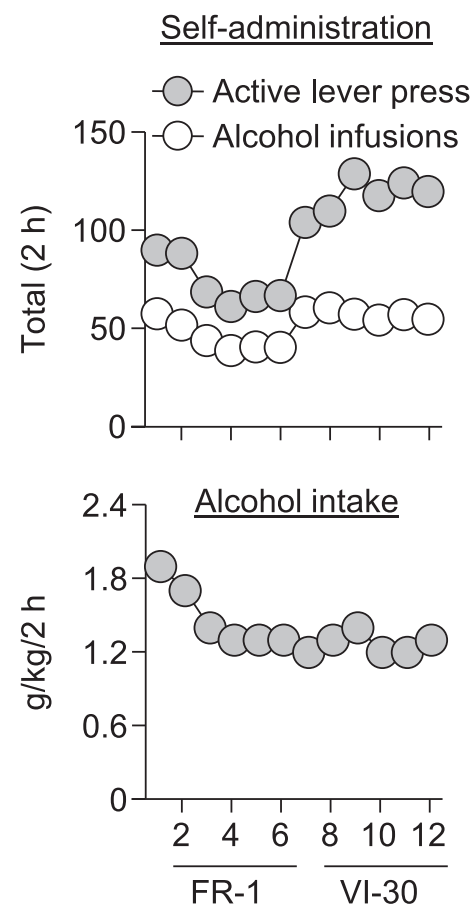

Reinforcement schedule
D Context B punishment
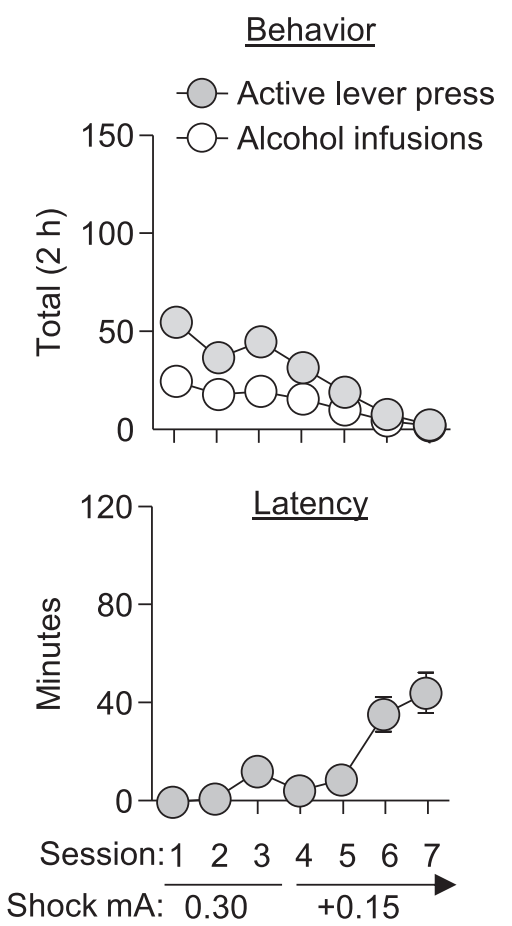

Figure 1. Home-cage intake, initial alcohol self-administration in context $A$, and subsequent alcohol self-administration in context $B$ (punishment). $A$, Outline of the experimental procedure before test. B, Mean \pm SEM preference for $20 \%$ alcohol or water and alcohol intake (grams per kilogram) during the home-cage access to $20 \%$ alcohol. The SEMs for these data points are smaller than the symbol size. $C$, Mean active lever presses and alcohol deliveries and alcohol intake during the alcohol self-administration training in context $A$ ( 6 sessions with each reinforcement schedule). $D$, Mean active lever presses, alcohol deliveries, and latency to the first lever press during punishment in context $B$. After the third session, rats with $>15$ active lever presses in the $2 \mathrm{~h}$ session were given additional sessions with increased shock intensity. Data are from all rats in Experiments 1-3; total $n=69$.

Immediately after the 90 min test, we perfused the tested rats; we also perfused the no-test rats at the same time. Subsequently, we measured double labeling of CTb + Fos in projection areas of LH: NAc shell, vmPFC, dmPFC, LS, vBNST, and dBNST. We excluded rats with misplaced $\mathrm{CTb}$ injections from the $\mathrm{CTb}+$ Fos double-labeling analysis but kept them in the total Fos analysis. The group numbers for the CTb + Fos double-labeling analysis were as follows: alcohol context, $n=5$; punishment context, $n=5$; no-test, $n=3$. We also measured only Fos expression in NAc core, DLS, DMS, PVT, LHb, and MHb.

\section{Statistical analysis}

We analyzed the data separately for the four phases: (1) home-cage intake; (2) context A training; (3) context B punishment; and (4) renewal tests. For the renewal test, the dependent measures were total (nonreinforced) responses on the previously active lever and on the inactive lever. The dependent measures from the different immunohistochemistry assays were cell counts per square millimeter of a given brain area. We analyzed Fos, CTb, and CTb + Fos using a mixed ANOVA with the within-subjects factor of brain region and the between-subjects factor of group [context A (renewal), context B (punishment), and no-test]. We performed subsequent analyses on these measures within each brain re- gion by using one-way ANOVA and followed up significant main or interaction effects $(p<0.05)$ with Fisher's least significant difference post hoc tests.

\section{Results}

Alcohol-preferring $\mathrm{P}$ rats consumed high amounts of alcohol in the home-cage intermittent-access choice phase (Fig. 1B) and reliably self-administered alcohol in context A under the FR-1 and VI-30 reinforcement schedules (Fig. 1C). During punishment in context $\mathrm{B}$, the rats decreased alcohol self-administration with increased shock intensity (Fig. 1D).

Effect of context-induced renewal of alcohol seeking after punishment-imposed abstinence on Fos expression in LH hypocretin neurons

Relapse test

We observed context-induced renewal of alcohol seeking in context A after punishment of alcohol self-administration in context B (Fig. 2B). The ANCOVA of active lever presses (inactive lever 
A

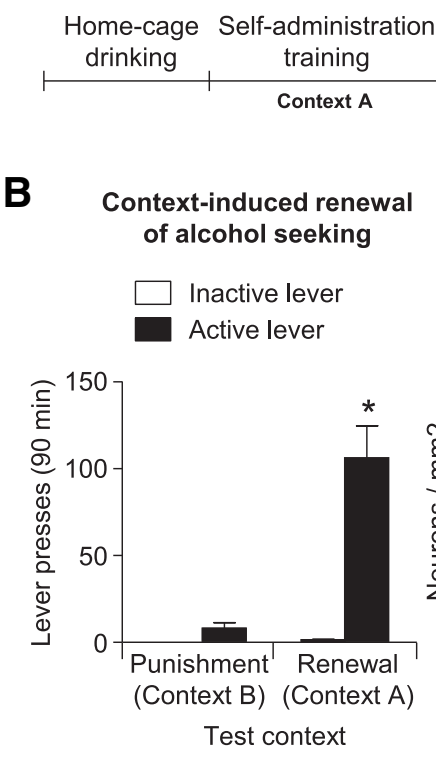

D

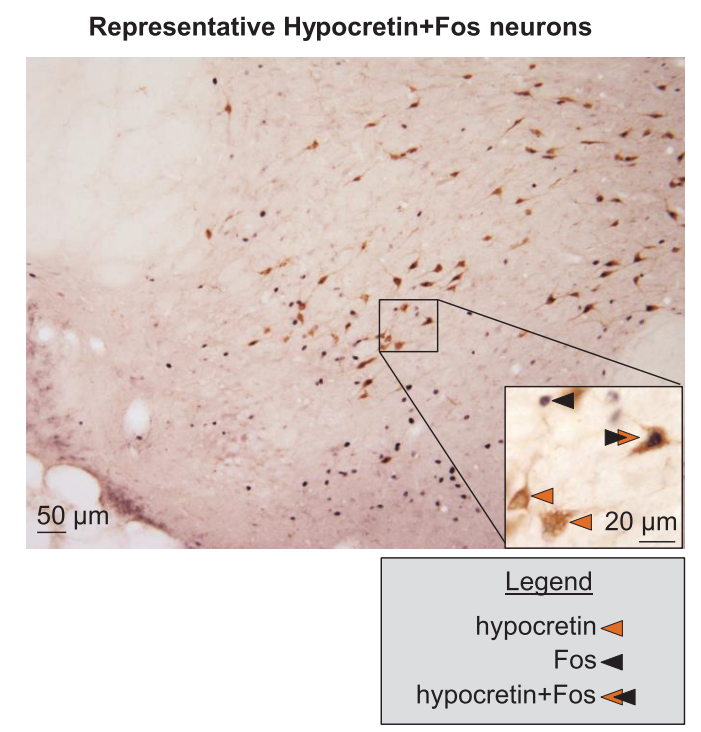

Figure 2. Effect of context-induced renewal of alcohol seeking after punishment-imposed abstinence on Fos expression in LH. $\boldsymbol{A}$, Outline of the experimental procedure for this experiment. $\boldsymbol{B}$, Renewal test: Mean \pm SEM active and inactive lever presses during testing. ${ }^{*} p<0.05$ different from the punishment context group. C, Hypocretin-IR, Fos-IR, and Fos + hypocretin-IR neurons: Number of IR neurons per square millimeter in the $L H$ of rats tested in punishment context $\mathrm{B}(n=8)$, alcohol training context $\mathrm{A}(n=8)$, or taken from the home cage (no-test, $n=5$ ). ${ }^{*} p<0.05$, different from the punishment context and no-test groups; ${ }^{\#} p<$ 0.05 , different from the no-test group. $\boldsymbol{D}$, Representative photomicrograph of hypocretin and Fos immunohistochemistry. Scale bar, $50 \mu \mathrm{m}$. Inset shows high-magnification example of IR neurons. Scale bar, $20 \mu \mathrm{m}$.

presses as a covariate) showed a significant effect of test context $\left(F_{(2,15)}=18.7, p<0.01\right)$.

Fos-IR and Fos + hypocretin-IR data

We found that context-induced renewal of alcohol seeking was associated with increased Fos expression in LH (Fig. 2C) and that this effect was not selective to $\mathrm{LH}$ hypocretin neurons. The ANOVA showed a significant effect of group [context A (renewal group), context B (punishment group), no-test group] for both Fos-IR $\left(F_{(2,18)}=10.9, p<0.01\right)$, and Fos + hypocretin-IR double-labeled neurons $\left(F_{(2,18)}=5.1, p<0.05\right)$ but no group differences in number of hypocretin-IR neurons $(p<0.05)$. For
A

\begin{tabular}{|c|c|c|c|}
\hline $\begin{array}{l}\text { Home-cage } \\
\text { drinking }\end{array}$ & $\begin{array}{l}\text { Self-administration } \\
\text { training }\end{array}$ & $\begin{array}{l}\text { Punishment } \\
\text { training }\end{array}$ & $\begin{array}{c}\text { Renewal } \\
\text { test }\end{array}$ \\
\hline $\begin{array}{r}\text { Intrac } \\
\text { cannulas }\end{array}$ & $\begin{array}{l}\text { Context A } \\
\text { ranial } \\
\text { surgery }\end{array}$ & Context B & $\begin{array}{c}\text { Context A \& B } \\
\text { Vehicle or Mus+Bac } \\
\text { LH injections }\end{array}$ \\
\hline
\end{tabular}

B Effect of LH inactivation on context-induced renewal of alcohol seeking

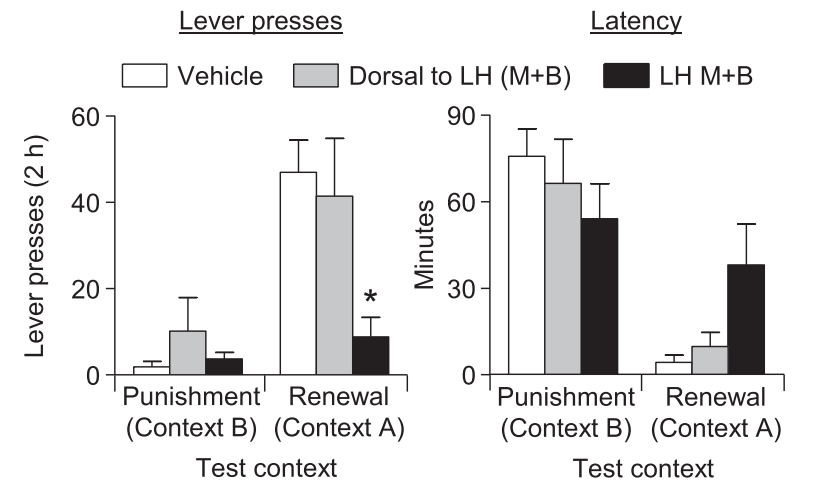

C

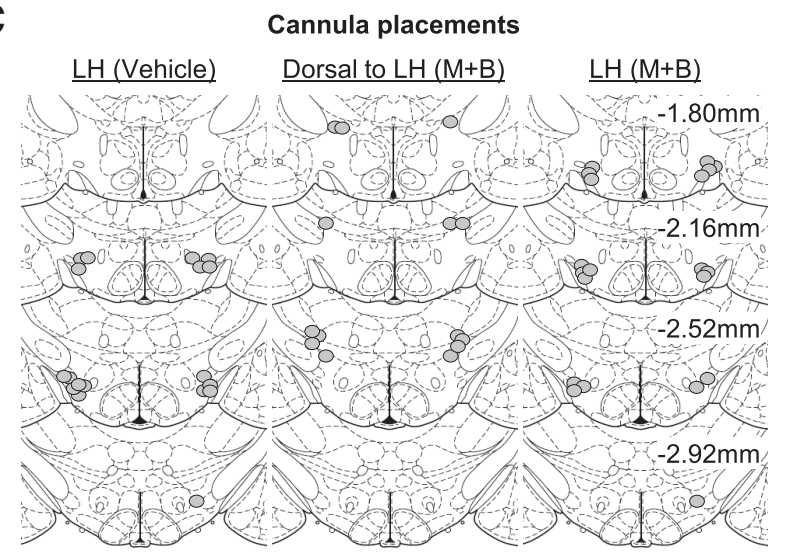

Figure 3. Effect of LH inactivation on context-induced renewal of alcohol seeking after punishment-imposed abstinence. $\boldsymbol{A}, 0$ utline of the experimental procedure for this experiment. $\boldsymbol{B}$, Mean \pm SEM active lever presses and latency to initiate alcohol seeking in three groups of rats that were injected with vehicle $(n=9)$, muscimol + baclofen $(\mathrm{M}+\mathrm{B})$ in $\mathrm{LH}(n=10)$, or dorsal to LH ( $n=7$ ). C, Approximate placements (millimeters from bregma) of the injector tips (Paxinos and Watson, 2008).

Fos-IR neurons, the post hoc analysis showed group differences between context A versus context B and no-test $(p<0.05)$, indicating that rats tested in context $\mathrm{A}$ had more Fos immunoreactivity in LH than rats tested in context B or not tested. For Fos + hypocretin-IR double-labeled neurons, analysis showed group differences between contexts $\mathrm{A}$ and $\mathrm{B}$ versus no-test $(p<0.05)$ but no differences between the rats tested in context A or B.

Effect of LH inactivation on context-induced renewal of alcohol seeking after punishment-imposed abstinence We found that muscimol + baclofen LH injections, but not dorsal to LH injections, decreased context-induced renewal of alcohol seeking after punishment (Fig. 3B). Analysis of active lever presses (inactive lever presses as a covariate) showed a significant interaction between test context (context A, context B, withinsubjects factor) and group (LH vehicle, $\mathrm{LH}$ muscimol + baclofen, dorsal to LH muscimol + baclofen, between-subjects factor) $\left(F_{(2,21)}=10.0, p<0.01\right)$. Analysis of latency to first lever press 
also showed a significant test context $\times$ group interaction $\left(F_{(1,23)}=\right.$ $4.7, p<0.05)$.

\section{Effect of context-induced renewal of alcohol seeking after punishment-imposed abstinence on Fos expression in brain areas projecting to $\mathrm{LH}$ \\ Relapse test}

We observed context-induced renewal of alcohol seeking in context A after punishment in context B (Fig. 4B). The ANCOVA of active lever presses (inactive lever presses as a covariate) showed a significant effect of test context $\left(F_{(2,16)}=76.0, p<0.01\right)$. As in Experiment 1, we analyzed results from three groups of rats that were either tested in context A (renewal group) or B (punishment group) or not tested (no-test group). Figure $4 C$ shows an example $\mathrm{CTb}$ injection in $\mathrm{LH}$, and Figure $4 \mathrm{G}$ shows the location of all $\mathrm{LH}$ $\mathrm{CTb}$ injections. There were no group differences for the number of CTb-labeled neurons in the different brain areas $\left(F_{(2,12)}<2.8\right.$, $p>0.05$; Table 1$)$.

Fos-IR data

Our initial analysis using brain region (NAc shell, LS, dBNST, LBNST, dmPFC, vmPFC) as the within-subjects factor and group as the between-subjects factor showed a significant interaction between the two factors $\left(F_{(10,85)}=4.1, p<0.01\right.$; Fig. $\left.4 E\right)$. In subsequent one-way ANOVAs, we found a significant effect of group for vmPFC, dmPFC, LS, and NAc shell $\left(F_{(2,21)}>5.7, p<\right.$ 0.01 ) but not in vBNST and dBNST. The significant effects of group were attributable to higher Fos immunoreactivity in the context A and context B groups than in the no-test group.

\section{$C T b+$ Fos-IR data}

Our initial factorial ANOVA of brain region (within-subjects factor) $\times$ group (between-subjects factor) showed main effects of $\operatorname{group}\left(F_{(2,8)}=5.3, p<0.05\right)$ and brain region $\left(F_{(5,40)}=12.0, p<\right.$ $0.01)$ but no interaction between the two factors $(p>0.1$; Fig. $4 F)$. In subsequent one-way ANOVAs, we found a significant or approaching significant effect of group in NAc shell $\left(F_{(2,12)}=\right.$ $21.6, p<0.01)$, LS $\left(F_{(2,12)}=3.5 ; p=0.071\right)$, and $\operatorname{vBNST}\left(F_{(2,12)}=\right.$ $3.7, p=0.072)$ but not in vmPFC, dmPFC, and dBNST. The most important results from the post hoc analyses were in NAc shell ( $p$ values $<0.05)$ and vBNST ( $p$ values $<0.055)$, in which the number of CTb + Fos-IR double-labeled neurons of the context A group was higher than both the context $\mathrm{B}$ and no-test groups. These data indicate selective activation of NAc shell neurons and potentially ventral BNST neurons that project to $\mathrm{LH}$ during context-induced renewal of alcohol seeking after punishmentimposed suppression of alcohol taking.

\section{Effect of context-induced renewal of alcohol seeking after punishment-imposed abstinence on Fos expression in other brain areas}

In an exploratory investigation, we also analyzed Fos expression of the rats used in Experiment 3 in brain areas implicated in context-induced reinstatement of drug seeking and aversive conditioning (see Introduction) in which we found minimal or no expression of LH-injected CTb. These include the NAc core, DLS and DMS (Fig. 5A), PVT, and LHb and MHb (Fig. 5C). Our initial factorial ANOVA of brain region $\times$ group showed a significant interaction between the two factors $\left(F_{(10,95)}=2.5, p=\right.$ 0.012 ). In subsequent one-way ANOVAs of each brain region, we found significant group effects for NAc core, DLS (but not DMS), PVT, LHb, and MHb ( $F$ values $>5.1, p<0.05)$. The most important findings from the post hoc analyses were for NAc core and DLS ( $p$ values $<0.01$ ), in which the number of Fos-IR neurons of the context A group was higher than both the context B and no-test groups. Another important finding was that, in LHb (but not $\mathrm{MHb}$ ), the number of Fos-IR neurons of the context B group (punished group) was higher than in both the context A (renewal) and no-test groups $(p=0.01)$. Thus, context-induced renewal after punishment-imposed abstinence is associated with selective activation of NAc core and DLS, whereas suppression of alcohol seeking in context B by previous punishment history is associated with selective activation of LHb.

\section{Discussion}

We studied the role of $\mathrm{LH}$ and forebrain projections to $\mathrm{LH}$ in renewal of alcohol seeking after punishment-imposed abstinence (Marchant et al., 2013b). We found that context-induced renewal of alcohol seeking was associated with increased LH Fos expression, which was not selective to LH hypocretin neurons. Reversible inactivation of LH blocked this context-induced renewal of alcohol seeking; this effect was anatomically specific because injections dorsal to LH were ineffective. Our CTb + Fos doublelabeling data demonstrate that NAc shell neurons projecting to LH are activated during context-induced renewal of alcohol seeking. Our CTb + Fos double-labeling data also potentially suggest that context-induced renewal of alcohol seeking is associated with activation of vBNST neurons projecting to LH. However, these results only approached statistical significance and should be interpreted with caution. Finally, we found that contextinduced renewal of alcohol seeking is associated with activation of NAc core and DLS, whereas suppression of alcohol seeking in the punishment context is associated with activation of LHb.

\section{Role of LH and accumbens shell projections to $\mathrm{LH}$}

Our main finding is that context-induced renewal of alcohol seeking after punishment-imposed abstinence is associated with increased Fos expression in $\mathrm{LH}$ and that reversible inactivation of LH blocked this renewal. These findings extend previous evidence on the role of $\mathrm{LH}$ in context-induced and discriminative cue-induced renewal/reinstatement of alcohol seeking after extinction (Dayas et al., 2008; Marchant et al., 2009; Kallupi et al., 2010; Kallupi et al., 2013). However, in these previous studies, reinstatement/renewal of drug seeking was associated with increased Fos expression in LH hypocretin neurons, an effect that we did not observe (Fig. 2C). The reasons for this difference are unknown, but they suggest that LH hypocretin neurons contribute to context-induced renewal after extinction whereas nonhypocretin neurons in LH contribute to context-induced renewal after punishment.

Our second main finding is that renewal of alcohol seeking is associated with increased Fos expression in NAc shell projections to LH. This finding is similar to that from a previous study using the same methodology in which Marchant et al. (2009) reported that context-induced renewal of alcoholic beer seeking activates the same projection. Thus, activation of the NAc shell projection to $\mathrm{LH}$ is associated with renewal of alcohol seeking in context $\mathrm{A}$ in a manner that is independent of the mechanism used to suppress alcohol seeking in context $\mathrm{B}$. However, a difference between the two studies is the pattern of Fos expression in dorsal NAc shell in context B. Marchant et al. (2009) reported higher CTb + Fos double-labeling in this shell subregion in rats tested in the extinction (B) context than rats tested in the training (A) context. In contrast, we did not observe a selective increase in $\mathrm{CTb}+$ Fos double labeling in dorsal NAc shell in rats tested in the punishment context (data not shown). 
A

\begin{tabular}{cccc}
$\begin{array}{c}\text { Home-cage } \\
\text { drinking }\end{array}$ & $\begin{array}{c}\text { Self-administration } \\
\text { training }\end{array}$ & $\begin{array}{c}\text { Punishment } \\
\text { training }\end{array}$ & $\begin{array}{c}\text { Renewal } \\
\text { test }\end{array}$ \\
\hline $\begin{array}{c}\text { LH CTb } \\
\text { injections }\end{array}$ & Context A & Context B & $\begin{array}{c}\text { Context A or B } \uparrow \\
\text { Perfusions for }\end{array}$ \\
& & & $\begin{array}{c}\text { Fos-IR + CTb-IR } \\
\text { Fos }\end{array}$
\end{tabular}
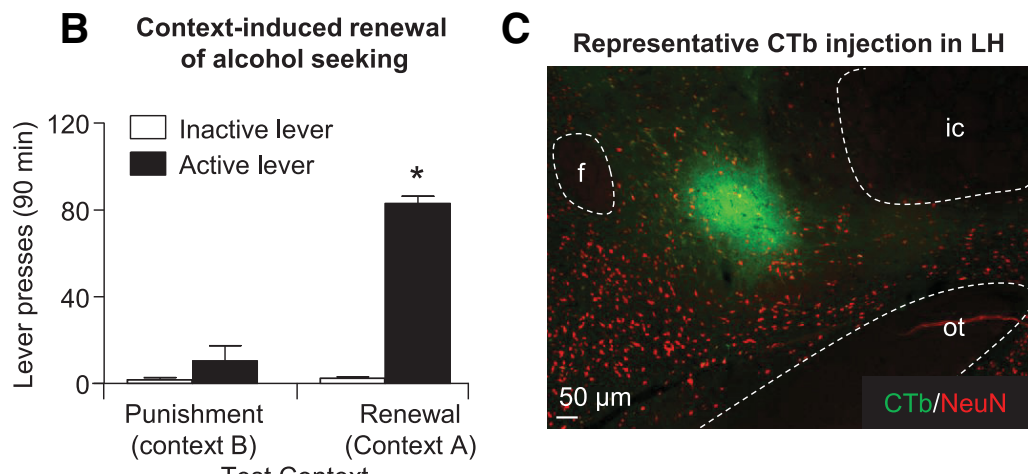

D Test Context

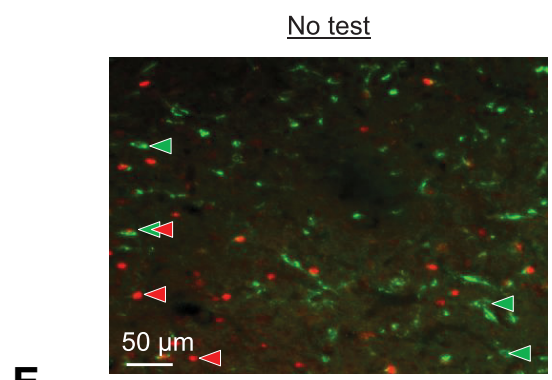

E
Punishment context B

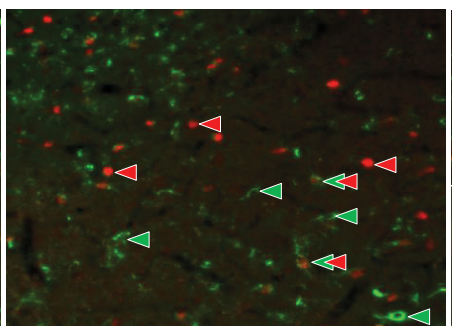

$\underline{\text { Renewal context A }}$

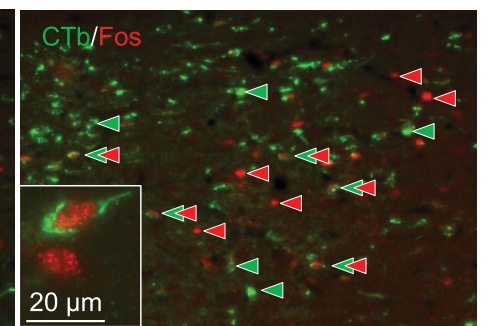

No test

Punishment context B

Renewal context $A$

Legend

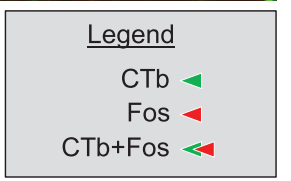

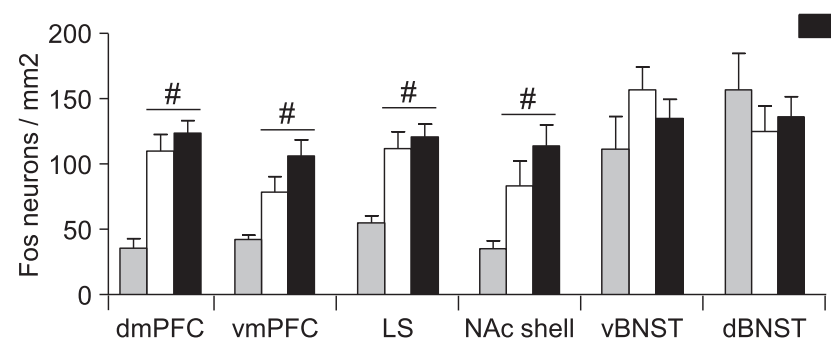

$\mathbf{F}$

Total number of CTb+Fos-IR neurons

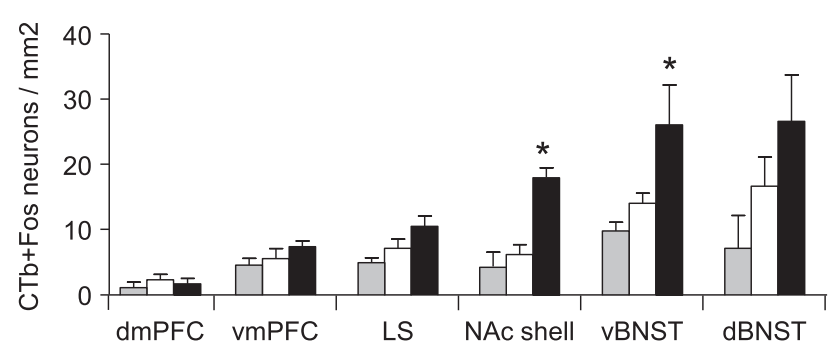

G Lateral Hypothalamus CTb injections
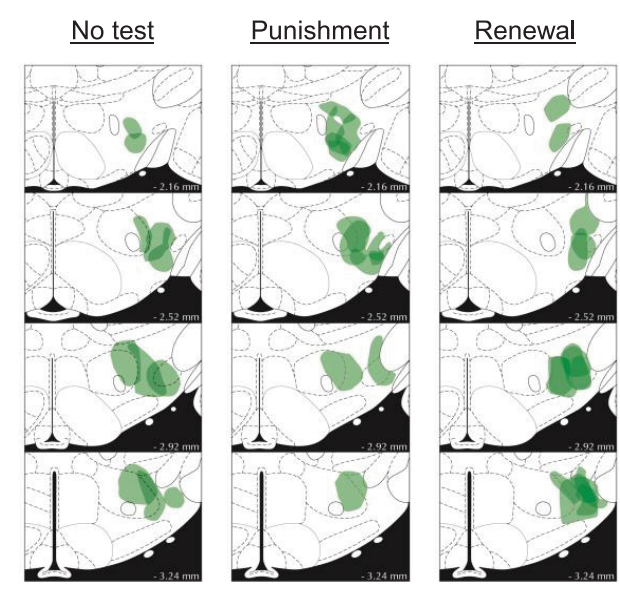

Figure 4. Effect of context-induced renewal of alcohol seeking after punishment-imposed abstinence on Fos expression in brain areas projecting to the LH. $\boldsymbol{A}$, Outline of the experimental procedure for this experiment. $\boldsymbol{B}$, Renewal test: Mean \pm SEM active and inactive lever presses during testing. ${ }^{*} p<0.05$ different from the punishment context group. $\boldsymbol{C}$, Representative photomicrograph of a CTb injection into LH. Scale bar, $50 \mu \mathrm{m}$. A counterstain of NeuN was used to define anatomy. f, Fornix; ic, internal capsule; ot, optic tract. D, Representative photomicrographs of CTb and Fos immunofluorescence in vBNST. Scale bar, $50 \mu \mathrm{m}$. Inset shows high-magnification example of IR neurons. Scale bar, $20 \mu \mathrm{m}$. E, Fos-IR neurons: Number of Fos-IR nuclei per square millimeter of rats tested in the punishment context $\mathrm{B}(n=8)$, alcohol training context $\mathrm{A}(n=8)$, or not tested $(n=6) .{ }^{\#} p<0.05$, different from the no-test group. $F$, CTb + Fos-IR double-labeled neurons: Number of double-labeled neurons per square millimeter in LH projection. ${ }^{*} p<0.055$, different from the punishment context and no-test groups. G, Schematic drawings of four different stereotaxic levels adapted from Paxinos and Watson (2008) in which correct CTb injections were confirmed with immunohistochemistry. Numbers represent millimeters from bregma. Each injection is plotted at $50 \%$ opacity so that overlap of injection sites is apparent with increased color intensity. 
Table 1. Mean \pm SEM quantification (per $\mathrm{mm}^{2}$ ) of CTb-IR, Fos-IR, and percentage double-labeled CTb + Fos neurons after LH CTb injections

\begin{tabular}{lccc}
\hline & Fos $\left(\mathrm{mm}^{2}\right)$ & $\left(\mathrm{Tb}\left(\mathrm{mm}^{2}\right)\right.$ & \% CTb + Fos/Total CTb \\
\hline dmPFC & & & \\
$\quad$ No test & $35.7 \pm 7.2$ & $17.1 \pm 4.6$ & $5.6 \pm 3.4$ \\
$\quad$ Punishment & $110.2 \pm 12.5$ & $43.6 \pm 15.7$ & $6.3 \pm 1.7$ \\
$\quad$ Alcohol & $123.8 \pm 9.5$ & $25.7 \pm 8.0$ & $6.3 \pm 2.0$ \\
vmPFC & & & \\
$\quad$ No test & $42.2 \pm 3.5$ & $104.6 \pm 8.5$ & $4.4 \pm 0.7$ \\
$\quad$ Punishment & $78.7 \pm 11.7$ & $152.1 \pm 14.9$ & $3.8 \pm 0.9$ \\
$\quad$ Alcohol & $106.3 \pm 12.2$ & $130.7 \pm 11.9$ & $5.8 \pm 0.6$ \\
LS No test & & & \\
$\quad$ No & $57.7 \pm 5.8$ & $139.7 \pm 21.6$ & $3.7 \pm 0.7$ \\
$\quad$ Punishment & $104.9 \pm 12.7$ & $122.7 \pm 14.2$ & $6.2 \pm 1.4$ \\
$\quad$ Alcohol & $121.0 \pm 9.7$ & $130.2 \pm 11.5$ & $8.2 \pm 0.9$ \\
NAc shell & & & \\
$\quad$ No test & $35.5 \pm 6.2$ & $212.8 \pm 46.0$ & $1.8 \pm 0.6$ \\
$\quad$ Punishment & $77.7 \pm 20.9$ & $238.9 \pm 22.0$ & $2.7 \pm 0.5$ \\
$\quad$ Alcohol & $114.0 \pm 13.0$ & $264.0 \pm 18.8$ & $6.9 \pm 0.4 *$ \\
dBNST & & & \\
$\quad$ No test & $157.0 \pm 27.9$ & $151.5 \pm 65.2$ & $4.1 \pm 1.6$ \\
$\quad$ Punishment & $125.1 \pm 19.7$ & $183.9 \pm 26.0$ & $10.1 \pm 2.8$ \\
$\quad$ Alcohol & $136.2 \pm 15.4$ & $226.2 \pm 33.4$ & $11.5 \pm 2.1$ \\
vBNST & & & \\
$\quad$ No test & $111.4 \pm 25.0$ & $148.0 \pm 33.0$ & $6.8 \pm 0.6$ \\
Punishment & $156.8 \pm 17.6$ & $192.6 \pm 23.8$ & $7.8 \pm 1.2$ \\
Alcohol & $135.0 \pm 14.8$ & $184.2 \pm 10.8$ & $14.1 \pm 3.0$ \\
\hline & & &
\end{tabular}

The functional significance of context-specific activation of the NAc shell projection to LH during the renewal tests is unknown. Activation of this GABAergic projection should increase GABA release in $\mathrm{LH}$, which, based on our muscimol + baclofen inactivation data, should inhibit rather than promote contextinduced renewal of alcohol seeking. This idea fits with results demonstrating increased food intake by pharmacological inhibition of NAc shell by GABA receptor agonists or glutamate receptor antagonists, an effect inhibited by $\mathrm{LH}$ inactivation (Maldonado-Irizarry et al., 1995; Stratford and Kelley, 1999; Baldo et al., 2013). An alternative speculative possibility is that activation of NAc shell projections to LH promotes contextinduced renewal of alcohol seeking. This may occur if the activated projection neurons selectively inhibit LH GABAergic interneurons (Karnani et al., 2013), which normally inhibit LH output neurons.

\section{Role of NAc core, dorsolateral striatum, and LHb}

We found that context-induced renewal of alcohol seeking after punishment-imposed abstinence is associated with activation of NAc core and DLS, whereas suppression of alcohol seeking in context $\mathrm{B}$ by previous punishment history is associated with activation of LHb (Fig. 5). The NAc core was implicated previously in context-induced renewal of alcohol and cocaine (but not heroin) seeking after extinction (Bossert et al., 2007; Fuchs et al., 2008a; Chaudhri et al., 2009). The DLS was implicated previously in context-induced renewal of cocaine and heroin seeking after extinction (Fuchs et al., 2006; Bossert et al., 2009). To the degree that similar mechanisms control context-induced renewal after extinction or punishment (see below), we predict that future studies will demonstrate causal roles of NAc core and DLS in context-induced renewal of drug seeking after punishment.

The LHb was implicated in aversive motivational states and avoidance behavior (Lammel et al., 2012; Jhou et al., 2013), which is potentially consistent with our finding of increased activation of LHb in rats tested in context B after punishment-imposed
A
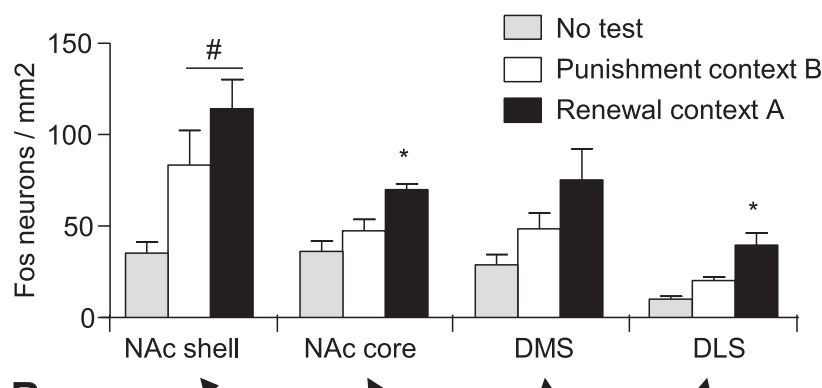

B
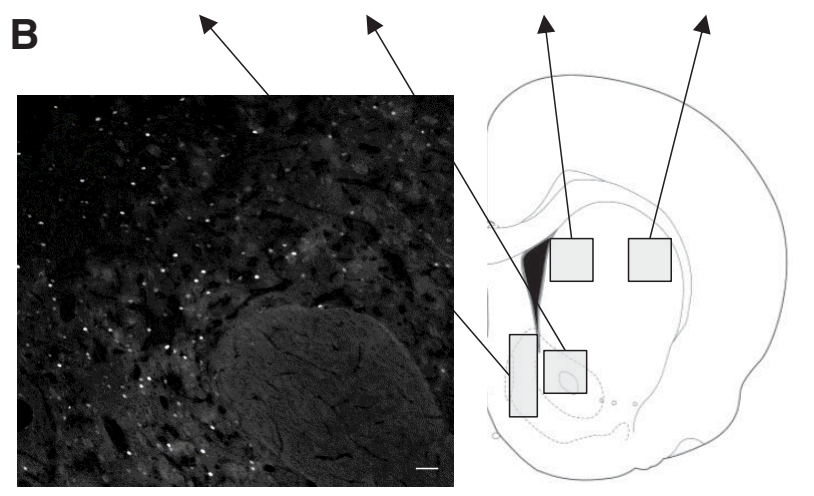

C

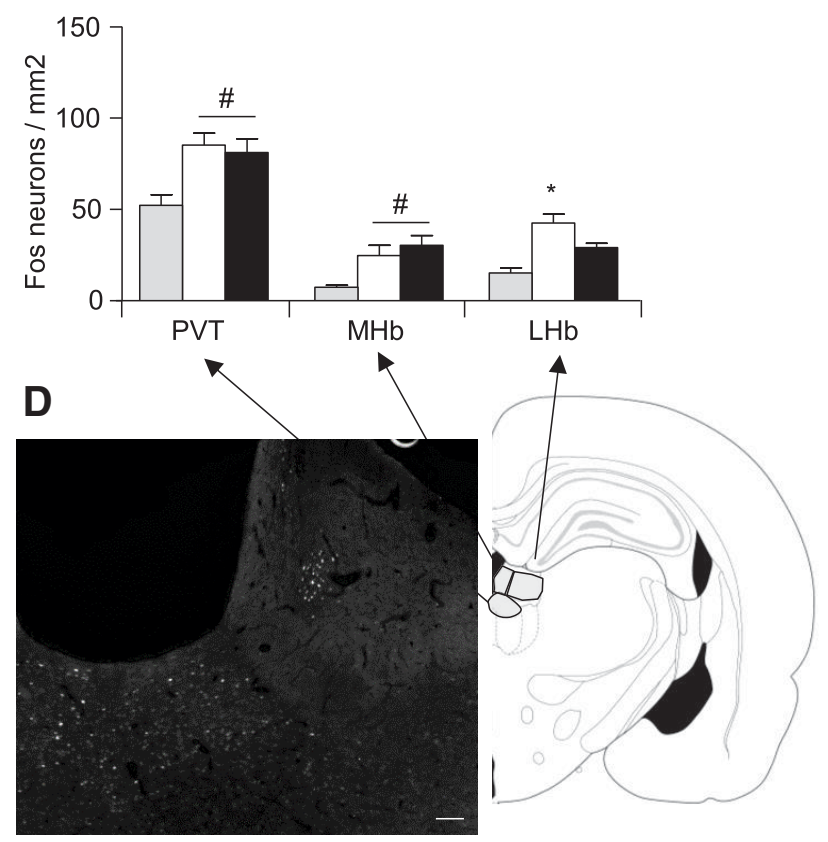

Figure 5. Effect of context-induced renewal of alcohol seeking after punishment-imposed abstinence on Fos expression in additional brain areas. $\boldsymbol{A}$, Number of Fos-IR nuclei per square millimeter in the striatum of rats tested in the punishment context $(\boldsymbol{B})(n=8)$, alcohol training context $(\boldsymbol{A})(n=8)$, or not tested $(n=6)$. $\boldsymbol{B}$, Representative photomicrograph of Fos immunofluorescence in NAc core. Scale bar, $50 \mu \mathrm{m}$. $\boldsymbol{C}$, Number of Fos-IR nuclei per square millimeter in epithalamic brain regions of the same rats. $D$, Representative photomicrograph of Fos immunofluorescence in PVT and habenula. Scale bar, $100 \mu \mathrm{m}$. ${ }^{*} p<0.05$, renewal group different from the punishment group; ${ }^{\#} p<0.05$, different from the no-test group.

suppression of alcohol self-administration (Fig. 5C). This selective LHb activation is consistent with the results of Mahler and Aston-Jones (2012) that extinction of cocaine seeking is associated with increased activity of LHb projections to VTA. Together, these findings provide additional evidence that LHb might be an 
important region for suppression of drug seeking (Friedman et al., 2010).

One methodological consideration in the interpretation of Fos data, particularly in reference to suppression of drug seeking, is that brain Fos levels are very low under basal conditions (Morgan and Curran, 1991). Thus, if suppression of drug seeking is mediated by a physiological mechanism that inhibits neuronal activity, such a mechanism cannot be detected by measuring Fos. Another methodological consideration is whether suppression of responding in context $\mathrm{B}$ is attributable to the history of responsecontingent operant punishment or response-independent Pavlovian shock-context association. We argue that punishment contingencies are critical, because we found previously that alcohol self-administration and extinction responding during testing were similar in rats receiving noncontingent (random) shocks to rats receiving no shock in context B (Marchant et al., 2013b).

\section{Implications to animal models of drug relapse}

The main empirical question that inspired our studies on context-induced renewal after punishment-imposed abstinence (Marchant et al., 2013b) is whether similar or different mechanisms mediate context-induced renewal after extinction versus context-induced renewal in a procedure in which abstinence is achieved by adverse consequences of drug taking rather than by operant extinction. This question is important, because it has been argued over the years that the use of operant extinction limits the validity of the extinction-reinstatement procedure as a model of human drug relapse (Marlatt, 1996; Everitt and Robbins, 2000; Katz and Higgins, 2003).

Our study provides the first mechanistic data on renewal of alcohol seeking after punishment-imposed abstinence, which we can compare with previous studies on renewal of alcohol seeking after extinction. Although comparison across studies in which experimental conditions differ (beyond extinction vs punishment) should be made with caution, we found several mechanistic similarities. Both renewal after punishment and renewal after extinction are associated with increased Fos expression in LH and selective recruitment of NAc shell projections to LH (Hamlin et al., 2007; Marchant et al., 2009, 2010). Additionally, reversible inactivation of LH blocks both context-induced renewal after punishment and context-induced renewal after extinction (Marchant et al., 2009). These findings suggest that the LH is critical for renewal of alcohol seeking regardless of the mechanism used to suppress alcohol seeking in context B. However, our data also suggest mechanistic differences. As mentioned above, context-induced renewal of alcohol seeking after extinction appears to recruit LH hypocretin neurons (Hamlin et al., 2007), whereas context-induced renewal of alcohol seeking after punishment does not.

There is also evidence from other studies on differences in mechanisms of reinstatement after extinction versus after punishment in rats trained to self-administer intravenous drugs (Marchant et al., 2013a). Panlilio et al. (2005) found that, in rats trained to self-administer remifentanyl (a shortacting opiate receptor agonist), priming injections of the benzodiazepine lorazepam had no effect on reinstatement after extinction but provoked reinstatement of drug seeking after punishment-imposed suppression of remifentanyl selfadministration. Additionally, Pelloux et al. (2013) found that pretraining lesions of the dorsal mPFC inhibit cue-induced cocaine seeking after punishment-imposed suppression of cocaine self-administration and 1 week of home-cage abstinence (cue-induced relapse was assessed in an extinction test). In contrast, Koya et al. (2009) and Fuchs et al. (2006) found that reversible inactivation of the dmPFC has no effect on cueinduced relapse to cocaine seeking after several weeks of abstinence.

In summary, although the present results and previous results (McNally, 2014) suggest an important role of the LH in renewal to alcohol seeking, which is independent of the method used to achieve abstinence in the alternative context, it is likely that future studies will identify both similarities and differences in mechanisms of relapse after suppression of the drug-reinforced responding by extinction versus punishment or other adverse consequences.

Finally, both emerging and historical literature suggest that mechanisms of both drug relapse (Bossert et al., 2013) and drug reward (Ettenberg et al., 1982; Mello and Negus, 1996; Badiani, 2013) differ among drug classes. Additionally, recent evidence indicates that drug-associated contexts differentially modulate alcohol, cocaine, and heroin taking and seeking. For example, rats prefer to self-administer alcohol or heroin in their home environment but cocaine or methamphetamine in a different (non-home) environment (Caprioli et al., 2008; Celentano et al., 2009; Testa et al., 2011; Badiani, 2013). A question for future research is whether the LH activity also mediates contextinduced renewal of opiate and psychostimulant seeking after punishment-imposed abstinence.

\section{References}

Aston-Jones G, Smith RJ, Sartor GC, Moorman DE, Massi L, Tahsili-Fahadan P, Richardson KA (2010) Lateral hypothalamic orexin/hypocretin neurons: a role in reward-seeking and addiction. Brain Res 1314:74-90. CrossRef Medline

Badiani A (2013) Substance-specific environmental influences on drug use and drug preference in animals and humans. Curr Opin Neurobiol 23: 588-596. CrossRef Medline

Baldo BA, Pratt WE, Will MJ, Hanlon EC, Bakshi VP, Cador M (2013) Principles of motivation revealed by the diverse functions of neuropharmacological and neuroanatomical substrates underlying feeding behavior. Neurosci Biobehav Rev 37:1985-1998. CrossRef Medline

Blume AW, Schmaling KB, Marlatt GA (2006) Recent drinking consequences, motivation to change, and changes in alcohol consumption over a three month period. Addict Behav 31:331-338. CrossRef Medline

Bossert JM, Poles GC, Wihbey KA, Koya E, Shaham Y (2007) Differential effects of blockade of dopamine D1-family receptors in nucleus accumbens core or shell on reinstatement of heroin seeking induced by contextual and discrete cues. J Neurosci 27:12655-12663. CrossRef Medline

Bossert JM, Wihbey KA, Pickens CL, Nair SG, Shaham Y (2009) Role of dopamine D1-family receptors in dorsolateral striatum in contextinduced reinstatement of heroin seeking in rats. Psychopharmacology 206:51-60. CrossRef Medline

Bossert JM, Stern AL, Theberge FRM, Marchant NJ, Wang HL, Morales M, Shaham Y (2012) Role of projections from ventral medial prefrontal cortex to nucleus accumbens shell in context-induced reinstatement of heroin seeking. J Neurosci 32:4982-4991. CrossRef Medline

Bossert JM, Marchant NJ, Calu DJ, Shaham Y (2013) The reinstatement model of drug relapse: recent neurobiological findings, emerging research topics, and translational research. Psychopharmacology (Berl) 229:453476. CrossRef Medline

Bouton ME (1993) Context, time, and memory retrieval in the interference paradigms of Pavlovian learning. Psychol Bull 114:80-99. CrossRef Medline

Bouton ME, Bolles RC (1979) Contextual control of the extinction of conditioned fear. Learn Motiv 10:445-466. CrossRef

Burman S (1997) The challenge of sobriety: natural recovery without treatment and self-help groups. J Subst Abuse 9:41-61. CrossRef Medline

Caprioli D, Celentano M, Paolone G, Lucantonio F, Bari A, Nencini P, Badiani A (2008) Opposite environmental regulation of heroin and amphetamine self-administration in the rat. Psychopharmacology (Berl) 198: 395-404. CrossRef Medline

Celentano M, Caprioli D, Dipasquale P, Cardillo V, Nencini P, Gaetani S, 
Badiani A (2009) Drug context differently regulates cocaine versus heroin self-administration and cocaine- versus heroin-induced Fos mRNA expression in the rat. Psychopharmacology (Berl) 204:349-360. CrossRef Medline

Chaudhri N, Sahuque L, Janak P (2009) Ethanol seeking triggered by environmental context is attenuated by blocking dopamine D1 receptors in the nucleus accumbens core and shell in rats. Psychopharmacology (Berl) 207:303-314. CrossRef Medline

Collins BN, Brandon TH (2002) Effects of extinction context and retrieval cues on alcohol cue reactivity among nonalcoholic drinkers. J Consult Clin Psychol 70:390-397. CrossRef Medline

Crombag HS, Bossert JM, Koya E, Shaham Y (2008) Context-induced relapse to drug seeking: a review. Philos Trans R Soc B Biol Sci 363:32333243. CrossRef Medline

Dayas CV, McGranahan TM, Martin-Fardon R, Weiss F (2008) Stimuli linked to ethanol availability activate hypothalamic CART and orexin neurons in a reinstatement model of relapse. Biol Psychiatry 63:152-157. CrossRef Medline

de Lecea L, Kilduff TS, Peyron C, Gao X, Foye PE, Danielson PE, Fukuhara C, Battenberg EL, Gautvik VT, Bartlett FS 2nd, Frankel WN, van den Pol AN, Bloom FE, Gautvik KM, Sutcliffe JG (1998) The hypocretins: hypothalamus-specific peptides with neuroexcitatory activity. Proc Natl Acad Sci U S A 95:322-327. CrossRef Medline

Epstein DH, Preston KL (2003) The reinstatement model and relapse prevention: a clinical perspective. Psychopharmacology (Berl) 168:31-41. CrossRef Medline

Ettenberg A, Pettit HO, Bloom FE, Koob GF (1982) Heroin and cocaine intravenous self-administration in rats: mediation by separate neural systems. Psychopharmacology (Berl) 78:204-209. CrossRef Medline

Everitt BJ, Robbins TW (2000) Second-order schedules of drug reinforcement in rats and monkeys: measurement of reinforcing efficacy and drugseeking behaviour. Psychopharmacology (Berl) 153:17-30. CrossRef Medline

Friedman A, Lax E, Dikshtein Y, Abraham L, Flaumenhaft Y, Sudai E, BenTzion M, Ami-Ad L, Yaka R, Yadid G (2010) Electrical stimulation of the lateral habenula produces enduring inhibitory effect on cocaine seeking behavior. Neuropharmacology 59:452-459. CrossRef Medline

Friedman A, Lax E, Dikshtein Y, Abraham L, Flaumenhaft Y, Sudai E, BenTzion M, Yadid G (2011) Electrical stimulation of the lateral habenula produces an inhibitory effect on sucrose self-administration. Neuropharmacology 60:381-387. CrossRef Medline

Fuchs RA, Branham RK, See RE (2006) Different neural substrates mediate cocaine seeking after abstinence versus extinction training: a critical role for the dorsolateral caudate-putamen. J Neurosci 26:3584-3588. CrossRef Medline

Fuchs RA, Ramirez DR, Bell GH (2008a) Nucleus accumbens shell and core involvement in drug context-induced reinstatement of cocaine seeking in rats. Psychopharmacology (Berl) 200:545-556. CrossRef Medline

Fuchs RA, Lasseter HC, Ramirez DR, Xie X (2008b) Relapse to drug seeking following prolonged abstinence: the role of environmental stimuli. Drug Discov Today Dis Models 5:251-258. CrossRef Medline

Hamlin AS, Newby J, McNally GP (2007) The neural correlates and role of D1 dopamine receptors in renewal of extinguished alcohol-seeking. Neuroscience 146:525-536. CrossRef Medline

Harris GC, Aston-Jones G (2006) Arousal and reward: a dichotomy in orexin function. Trends Neurosci 29:571-577. CrossRef Medline

Harris GC, Wimmer M, Aston-Jones G (2005) A role for lateral hypothalamic orexin neurons in reward seeking. Nature 437:556-559. CrossRef Medline

Heimer L, Zahm DS, Churchill L, Kalivas PW, Wohltmann C (1991) Specificity in the projection patterns of accumbal core and shell in the rat. Neuroscience 41:89-125. CrossRef Medline

Hoebel BG, Teitelbaum P (1962) Hypothalamic control of feeding and selfstimulation. Science 135:375-377. CrossRef Medline

Janak PH, Chaudhri N (2010) The potent effect of environmental context on relapse to alcohol-seeking after extinction. Open Addict J 3:76-87. CrossRef Medline

Jhou TC, Good CH, Rowley CS, Xu SP, Wang H, Burnham NW, Hoffman AF, Lupica CR, Ikemoto S (2013) Cocaine drives aversive conditioning via delayed activation of dopamine-responsive habenular and midbrain pathways. J Neurosci 33:7501-7512. CrossRef Medline

Kallupi M, Cannella N, Economidou D, Ubaldi M, Ruggeri B, Weiss F, Massi
M, Marugan J, Heilig M, Bonnavion P, de Lecea L, Ciccocioppo R (2010) Neuropeptide $S$ facilitates cue-induced relapse to cocaine seeking through activation of the hypothalamic hypocretin system. Proc Natl Acad Sci U S A 107:19567-19572. CrossRef Medline

Kallupi M, Guglielmo G, Cannella N, Li HW, Caló G, Guerrini R, Ubaldi M, Renger JJ, Uebele VN, Ciccocioppo R (2013) Hypothalamic neuropeptide $\mathrm{S}$ receptor blockade decreases discriminative cue-induced reinstatement of cocaine seeking in the rat. Psychopharmacology (Berl) 226:347-355. CrossRef Medline

Karnani MM, Szabó G, Erdélyi F, Burdakov D (2013) Lateral hypothalamic GAD65 neurons are spontaneously firing and distinct from orexin- and melanin-concentrating hormone neurons. J Physiol 591:933-953. CrossRef Medline

Katz JL, Higgins ST (2003) The validity of the reinstatement model of craving and relapse to drug use. Psychopharmacology (Berl) 168:21-30. CrossRef Medline

Kelley AE, Berridge KC (2002) The neuroscience of natural rewards: relevance to addictive drugs. J Neurosci 22:3306-3311. Medline

Klingemann HKH (1991) The motivation for change from problem alcohol and heroin use. Br J Addict 86:727-744. CrossRef Medline

Koya E, Uejima JL, Wihbey KA, Bossert JM, Hope BT, Shaham Y (2009) Role of ventral medial prefrontal cortex in incubation of cocaine craving. Neuropharmacology 56 [Suppl 1]:177-185. CrossRef

Lammel S, Lim BK, Ran C, Huang KW, Betley MJ, Tye KM, Deisseroth K, Malenka RC (2012) Input-specific control of reward and aversion in the ventral tegmental area. Nature 491:212-217. CrossRef Medline

Mahler SV, Aston-Jones GS (2012) Fos activation of selective afferents to ventral tegmental area during cue-induced reinstatement of cocaine seeking in rats. J Neurosci 32:13309-13326. CrossRef Medline

Maldonado-Irizarry CS, Swanson CJ, Kelley AE (1995) Glutamate receptors in the nucleus accumbens shell control feeding behavior via the lateral hypothalamus. J Neurosci 15:6779-6788. Medline

Marchant NJ, Hamlin AS, McNally GP (2009) Lateral hypothalamus is required for context-induced reinstatement of extinguished reward seeking. J Neurosci 29:1331-1342. CrossRef Medline

Marchant NJ, Furlong TM, McNally GP (2010) Medial dorsal hypothalamus mediates the inhibition of reward seeking after extinction. J Neurosci 30:14102-14115. CrossRef Medline

Marchant NJ, Millan EZ, McNally GP (2012) The hypothalamus and the neurobiology of drug seeking. Cell Mol Life Sci 69:581-597. CrossRef Medline

Marchant NJ, Li X, Shaham Y (2013a) Recent developments in animal models of drug relapse. Curr Opin Neurobiol 23:675-683. CrossRef Medline

Marchant NJ, Khuc TN, Pickens CL, Bonci A, Shaham Y (2013b) Contextinduced relapse to alcohol seeking after punishment in a rat model. Biol Psychiatry 73:256-262. CrossRef Medline

Margules DL, Olds J (1962) Identical "feeding" and "rewarding” systems in the lateral hypothalamus of rats. Science 135:374-375. CrossRef Medline

Marlatt AG (1996) Models of relapse and relapse prevention: a commentary. Exp Clin Psychopharmacol 4:55-60. CrossRef

McCusker CG, Brown K (1990) Alcohol-predictive cues enhance tolerance to and precipitate "craving" for alcohol in social drinkers. J Stud Alcohol 51:494-499. Medline

McFarland K, Kalivas PW (2001) The circuitry mediating cocaine-induced reinstatement of drug-seeking behavior. J Neurosci 21:8655-8663. Medline

McNally GP (2014) Extinction of drug seeking: neural circuits and approaches to augmentation. Neuropharmacology 76:528-532. Medline

Mello NK, Negus SS (1996) Preclinical evaluation of pharmacotherapies for treatment of cocaine and opioid abuse using drug self-administration procedures. Neuropsychopharmacology 14:375-424. CrossRef Medline

Morgan JI, Curran T (1991) Stimulus-transcription coupling in the nervous system: involvement of the inducible proto-oncogenes fos and jun. Annu Rev Neurosci 14:421-451. CrossRef Medline

O’Brien CP, Childress AR, McLellan AT, Ehrman R (1992) Classical conditioning in drug-dependent humans. Ann N Y Acad Sci 654:400-415. CrossRef Medline

Panlilio LV, Thorndike EB, Schindler CW (2005) Lorazepam reinstates punishment-suppressed remifentanil self-administration in rats. Psychopharmacology (Berl) 179:374-382. CrossRef Medline

Paxinos G, Watson C (2008) The rat brain in stereotaxic coordinates, Ed 6. San Diego: Academic. 
Pelloux Y, Murray JE, Everitt BJ (2013) Differential roles of the prefrontal cortical subregions and basolateral amygdala in compulsive cocaine seeking and relapse after voluntary abstinence in rats. Eur J Neurosci. Advance online publication. Retrieved April 24, 2014. doi:10.1111/ejn.12289. CrossRef

Simms JA, Steensland P, Medina B, Abernathy KE, Chandler LJ, Wise R, Bartlett SE (2008) Intermittent access to $20 \%$ ethanol induces high ethanol consumption in Long-Evans and Wistar rats. Alcohol Clin Exp Res 32:1816-1823. CrossRef Medline

Stratford TR, Kelley AE (1999) Evidence of a functional relationship between the nucleus accumbens shell and lateral hypothalamus subserving the control of feeding behavior. J Neurosci 19:11040-11048. Medline
Testa A, Nencini P, Badiani A (2011) The role of setting in the oral selfadministration of alcohol in the rat. Psychopharmacology (Berl) 215: 749-760. CrossRef Medline

Wikler A (1973) Dynamics of drug dependence: implications of a conditioning theory for research and treatment. Arch Gen Psychiatry 28:611616. CrossRef Medline

Wise RA (1973) Voluntary ethanol intake in rats following exposure to ethanol on various schedules. Psychopharmacologia 29:203-210. CrossRef Medline

Zahm DS, Heimer L (1993) Specificity in the efferent projections of the nucleus accumbens in the rat: comparison of the rostral pole projection patterns with those of the core and shell. J Comp Neurol 327:220-232. CrossRef Medline 